\title{
NECROLÓGIO
}

\section{JOSÉ DUARTE DE ARAÚJO (1934-1992)}

No início da décađa de 60, a Faculdade de Medicina da Bahia incrementou a renovação de seus métodos de ensino e criou condições para que uma geração de jovens médicos aperfeiçoasse seus conhecimentos no Exterior. Entre esses, estava o Dr. José Duarte de Araújo, natural de Juazeiro (Bahia), formado em medicina em 1959, que havia se destacado como estudante e terminado a Residência em Clínica Médica. Sob a influência do Prof. Roberto Santos, orientou-se para a Pediatria e esteve dois anos na Universidade John Hopkins, como bolsista da Fundação Kellogg. Ao regressar à Bahia, tornou-se Docente Livre de Clínica Pediátrica. Em 1966, fez Curso de Pediatria Social no Centre International de 1 'Enfance em Paris, começando a reorientar suas atividades no sentido da Saúde Pública. No ano seguinte, definiu a outra vertente de sua carreira profissional, como Administrador, ao aceitar o convite do Governador Luiz Viana para ser Secretário de Saúde do Estado da Bahia.

Em 1972, voltou aos Estados Unidos, para estudar Administração dos Cuidados Médicos, como bolsista da Organização Mundial da Saúde. Nessa oportunidade, diplomou-se em Mestre de Saúde Pública na Universidade da Califórnia, em Berkeley. Em 1974, foi aprovado em concurso para Professor Titular de Medicina Preventiva na Universidade Federal da Bahia, onde, também, foi Presidente da Câmara de Pós-Graduação e Pesquisa.

A partir de 1975, trabalhou como Coordenador de Ciências da Saúde do Conselho Nacional de Desenvolvimento Científico e Tecnológico (CNPq) e, posteriormente, como Diretor da Unidade de Pesquisa do CNPq e Vice-Presidente da mesma Instituição. Concomitantemente, foi Assessor do Ministério de Ciência e Tecnologia, da Organização Mundial da Saúde e Membro do STAC/TRD/ WHO.

Publicou mais de 40 trabalhos sobre saúde pública, financiamento de pequisas, tecnologia, desenvolvimento científico e recursos humanos. Mas, sua maior contribuição à área científica foi como Administrador. A Comunidade Científica, em geral, sempre contou com seu apoio nas reivindicações para melhores condições de trabalho. Especialmente na área de doenças infecciosas e parasitárias sua colaboração, através de sugestões e interferências, foi muitas vezes decisiva para o prosseguimento do Programa Integrado de Doenças Endêmicas (PIDE).

Ao lado de sua excelente formação profissional, o Dr. Duarte era trabalhador e inteligente. Conciliador e bem intencionado, buscava o consenso, sem transgredir com os aspectos fundamentais. Ajustou-se bem às funções que exercia por ser afável e de trato fácil. De caráter íntegro, mas modesto, sempre me deu a impressão de acreditar que os atos que inspiram nossa conduta compensariam por eles próprios, ou, como dizia Sêneca, "a recompensa a uma nobre ação está em a ter realizado".

A atitude mais natural diante da morte está em a esperar. Mas as coisas em si mesmas podem ter peso, medida e condições intrínsecas; dentro de nós, a alma as transforma como entende(Montaigne).

\section{Aluízio Prata}

